\title{
Compaction Characteristics of Lateritic Soil- Stabilized Municipal Solid Waste Bottom Sediment
}

\author{
A. Y. Abdulfatah, S. G. Kiru, and T. A. Adedokun
}

\begin{abstract}
An investigation has been made into the compaction characteristics of Lateritic Soil-Stabilized Municipal Solid Waste (MSW) Bottom Sediment. In particular, work has been directed towards determining to what extent the results of the British Standard Compaction Test for Lateritic Soils are affected by MSW Bottom Sediments. The bottom sediments of MSW from some selected dumping sites in Kano metropolis Nigeria were mixed with lateritic soils in different proportions and a compaction test was conducted on the mixtures. Maximum dry densities (MDD) of the mixtures

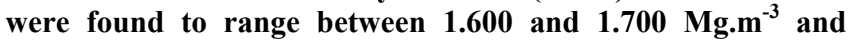
optimum moisture contents (OMC) were between $12 \%$ and $17 \%$. The results are similar to those of Silty Clay Soils of MDD between 1.600 and $1.845 \mathrm{Mg}^{-3}$ and OMC between $15 \%$ and $25 \%$. It is recommended that the bottom sediments be used as landfill or road construction materials after sorting out the re-cycled materials.
\end{abstract}

Index Terms-Compaction characteristics, landfills, municipal solid waste, soil stabilization.

\section{INTRODUCTION}

Any residue material which does not seem to have direct, indirect or immediate capacity to use but which can be recycled or reclaimed can be regarded as a waste material or matter [1]. Municipal solid waste is one that contains a significant amount of organic material which is highly compressible and is well known to deform and fail under load. It is characterized with low shear strength, and high water content. Municipal solid waste (MSW) also refers to the material discarded in the urban areas for which municipalities are usually held responsible for collection, transportation and final disposal. The question here, especially in developing countries like Nigeria, is how these solid wastes can be reused, reclaimed or re-cycled to produce other good products or services depending on technological development and the cost involved in such processes [2]. The existing problem of municipal solid waste is the huge daily generated quantity, non availability of efficient and economic means of waste disposal and perhaps the cost involved in using lateritic soils as landfill or road construction materials [3].

A number of researches exist to develop means through which waste can be useful (e.g. [4]. These means include improvement of the geotechnical properties of the waste bottom sediment by means of soil stabilization. The purpose

Manuscript received February 4, 2013; revised March 28, 2013. This work was jointly sponsored by the Kano State Government and Bayero University Kano all in Nigeria. The participation at the conference is sponsored by Bayero University, Kano.

A. Y. Abdulfatah is with Department of Civil Engineering, Faculty of Engineering, Bayero University Kano, P.M.B. 3011 Kano-Nigeria (e-mail: ayabdulfatah.civ@buk.edu.ng). of soil stabilization is to reduce permeability and improve compressibility, structural quality and workability of the municipal solid waste in order to reduce the problems of settlement to landfills reclamation. The task here is to find out the proportion of lateritic soil that would be just enough to stabilize the natural municipal solid waste such that it would be safe as a landfill material. Waste generation increases with an increase in household income, technology advancement and changes in life style. Large percentage of the waste is disposed in landfills and other sensitive places causing negative environmental impact and risk to human [5]. Reference [5] has categorized the MSW in the Nigerian urban areas into the following categories: a) domestic waste, b) commercial waste, c) institutional waste, d) industrial waste, e) street sweeping, f) demolition and construction debris, and g) others. This research focuses on determining the compaction characteristics of lateritic soil stabilized municipal solid waste bottom sediment after sorting out the recycled materials such as plastic, tin, copper, metals, lead etc. Traditionally in the area of this research, municipal solid waste is used without presorting for landfills reclamation, but this method has some deficiency due to excessive settlement encountered.

\section{MATERIALS AND METHOD}

\section{A. Experimental Parameters}

Municipal Solid Waste (MSW) samples were randomly collected from some selected dumping sites within the Kano metropolis. Sample (A) from Gyadi-Gyadi Court Road dumping site, Sample (B): Hajj Camp dumping site, Sample (C): Aminu Kano Way by Dala dumping site, Sample (D): Bompai Maimalari road dumping site, Sample (E): Tarauni by State Road dumping site, and Sample (F): Unguwa Uku by Local Government Secretariat dumping site. For all the collected samples, recycled materials including rubber, plastic, metals, etc. were sorted out. The bottom sediments of the MSW were then collected for the experimentation. Lateritic soil samples were obtained at a depth of $1.2 \mathrm{~m}$, from Janguza (Gwarzo Road) borrow pit. The MSW and soil samples were collected in five separate bags each and some relatively small portions of the collected samples were placed in air tight polyethene bags for the purpose of measuring natural moisture content. Random sampling was adopted in the collection for fair representation of the municipal solid waste bottom sediment after sorting out the recycled materials.

\section{B. Experimental Set-Up}

Mixtures of lateritic soil and the bottom sediments of MSW were prepared. The proportions used were 0, 10, 20, 30 and $40 \%$ respectively. At each stage of the test, a $3 \mathrm{~kg}$ 
mixture was air dried and pulverized sufficiently to run through no. $4 \mathrm{BS}$ sieve $(4.76 \mathrm{~mm})$. Thereafter, the required percentage of water (based on the dry weight) was added and thoroughly mixed until a uniform consistency was achieved. Compaction test was then conducted in accordance with [6] using the above sample mixtures [7]. The specimens were compacted in a standard BS mould of $105 \mathrm{~mm}$ diameter British Standard Light (BSL) dynamic compactive energy without delays, and a $2.5 \mathrm{~kg}$ rammer with $50 \mathrm{~mm}$ diameter head falling freely from $300 \mathrm{~mm}$ was used [8]. Compaction was effected in three layers each being given 25 blows. At the end of each compaction stage, the top of the mould was trimmed with a straight edge to remove excess soil. The mould and the sample of soil and MSW were weighed.

The calculations were as follows:

The bulk density, $\rho$ in $\mathrm{Mg}^{-3} \mathrm{~m}^{-3}$ of each compacted specimen was calculated from the equation:

$$
\rho=\frac{m_{2}-m_{1}}{100}\left(\mathrm{Mg} \cdot \mathrm{m}^{-3}\right)
$$

where: $m_{1}=$ Mass of mould and base $(\mathrm{kg})$

$m_{2}=\quad$ Mass of mould, base and soil $(\mathrm{kg})$

The dry density, $\rho_{d}$ was calculated from the equation

$$
\rho_{d}=\frac{100 \rho}{100+w}\left(\mathrm{Mg} \cdot \mathrm{m}^{-3}\right)
$$

\section{RESULTS}

The maximum dry density for the lateritic soil-stabilized MSW bottom sediments varied between $1.600 \mathrm{Mg} \cdot \mathrm{m}^{-3}$ and $1.700 \mathrm{Mg} \cdot \mathrm{m}^{-3}$, while the optimum moisture content ranged between $12 \%$ and $17 \%$ as shown in Table I and Fig. 1 to Fig. 5. In accordance with [9], the range of values that may be expected when using the standard proctor test of compaction method is as follows: maximum dry density; $1.600 \mathrm{Mg} \cdot \mathrm{m}^{-3}$ to $1.845 \mathrm{Mg} \cdot \mathrm{m}^{-3}$, and optimum moisture content; $15 \%$ to $25 \%$, for Silt

Clay. This has shown that the bottom sediment of MSW after sorting out all the re-cycled materials can be used as land filling or road construction material. The results indicate that the difference in maximum dry density between the higher value of $1.700 \mathrm{Mg} \cdot \mathrm{m}^{-3}$ and the lower of $1.600 \mathrm{Mg} \cdot \mathrm{m}^{-3}$ is $5.88 \%$. It can be concluded that there is not much difference in adding $0 \%$ to $40 \%$ lateritic soil to the bottom sediment before use. These sediments after a proper sorting can serve the purpose of a Silty Clay in a land filling or road construction activities [10].

TABLE I: MDD AND OMC AT VARIOUS SOIL CONTENTS

\begin{tabular}{|l|l|l|l|l|l|}
\hline Addition of Soil & $0 \%$ & $10 \%$ & $20 \%$ & $30 \%$ & $40 \%$ \\
\hline OMC (\%) & 17.0 & 16.0 & 12.0 & 14.6 & 16.0 \\
\hline MDD $\left(\mathrm{Mg} \cdot \mathrm{m}^{-3}\right)$ & 1.60 & 1.70 & 1.66 & 1.62 & 1.62 \\
\hline
\end{tabular}

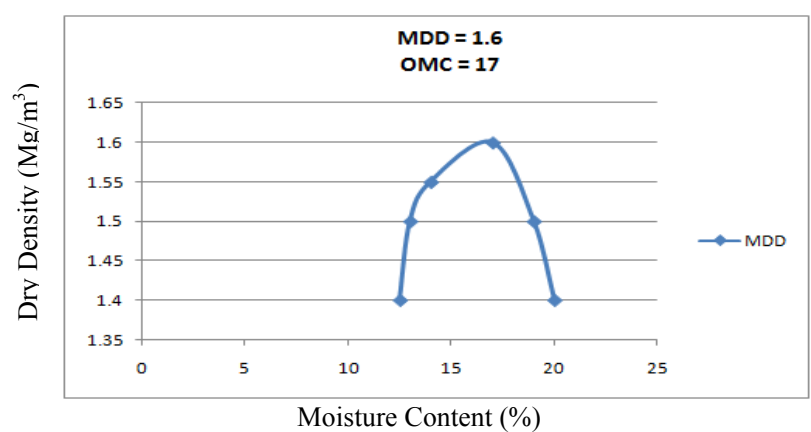

Fig. 1. Dry Density-Moisture Content Graph with 0\% Lateritic Soil

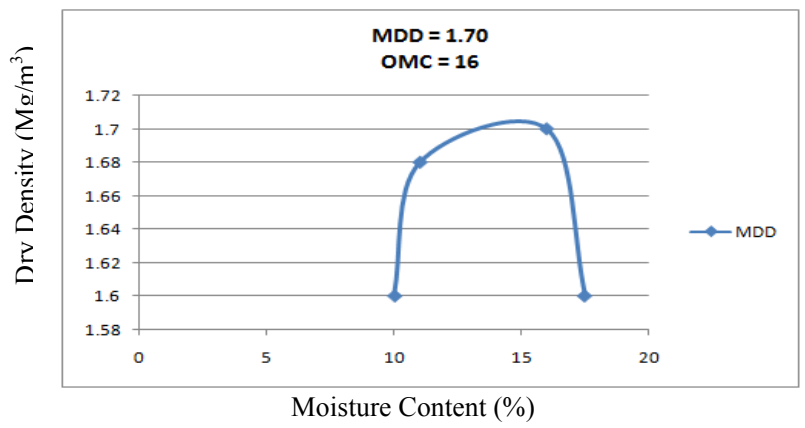

Fig. 2. Dry Density-Moisture Content Graph with 10\% Lateritic Soil

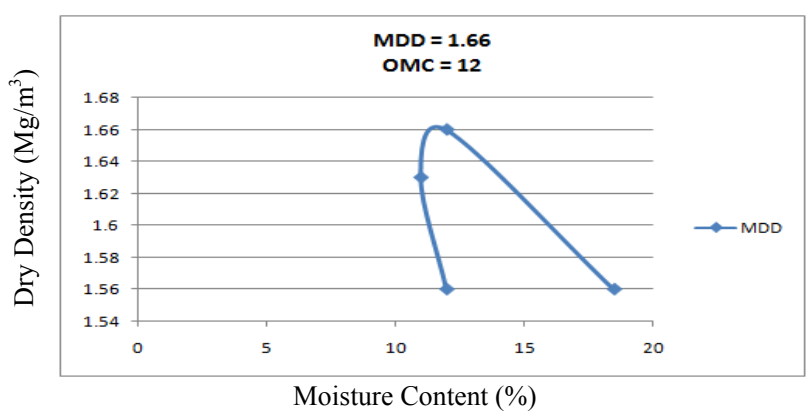

Fig. 3. Dry Density-Moisture Content Graph with 20\% Lateritic Soil

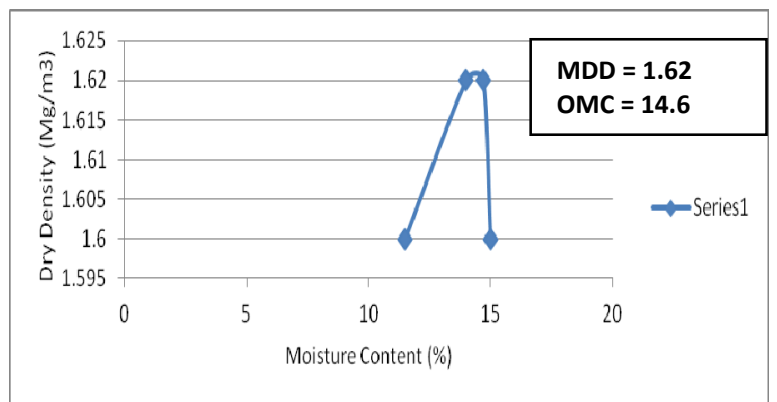

Fig. 4. Dry Density-Moisture Content Graph with 30\% Lateritic Soil

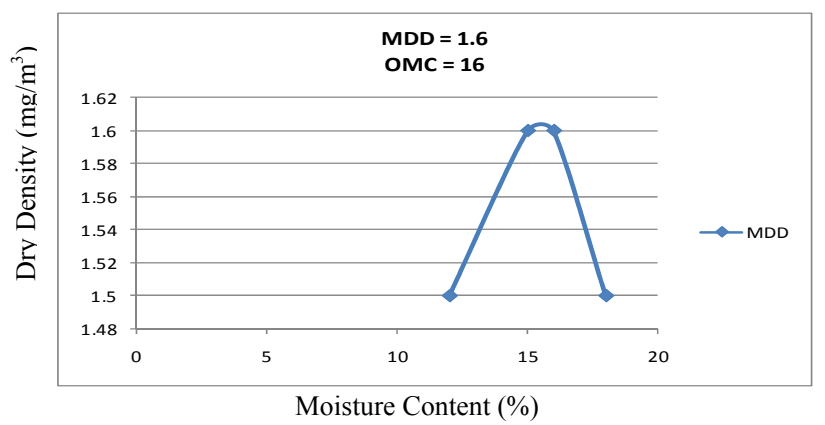

Fig. 5. Dry Density-Moisture Content Graph with 40\% Lateritic Soil 


\section{CONCLUSION}

The maximum dry density for the lateritic soil-stabilized MSW bottom sediments varied between $1.600 \mathrm{Mg} \cdot \mathrm{m}^{-3}$ and $1.700 \mathrm{Mg} \cdot \mathrm{m}^{-3}$, while the optimum moisture content ranged between $12 \%$ and $17 \%$. The results indicate that the difference in the maximum dry density between the higher value of $1.700 \mathrm{Mg} \cdot \mathrm{m}^{-3}$ and the lower of $1.600 \mathrm{Mg} \cdot \mathrm{m}^{-3}$ is $5.88 \%$. It can be concluded that there is not much difference in adding $0 \%$ to $40 \%$ lateritic soil to the bottom sediment before use. These sediments after a proper sorting can serve the purpose of a Silty Clay in land filling or road construction activities. It is recommended that the bottom sediments of MSW in urban areas in countries like Nigeria can be used as landfill or road construction materials after sorting out the re-cycled materials. This would save those areas from the problems of generated wastes and also from the cost of materials for landfill and road construction activities.

\section{REFERENCES}

[1] M. E. Henstock, "Disposal and Recovery of Municipal Solid Waste," Butter Worth \& Co. Ltd. Bratley, pp 4-21, 1983.

[2] B. Kalantari and B. B. K. Huat, "Peat Soil Stabilization, using Ordinary Portland Cement, Polypropylene Fibers and Air curingTechnique," Department of Civil Engineering, University of Putra Malaysia, pp. 1-13, 2004

[3] V. I. Ogu, "Private Sector Participation and Municipal Waste Management in Benin City, Nigeria," Journal of Environment and Urbanization, vol. 12, Issue 2, pp. 10-118, 2000.

[4] J. B. Fassett, G. A. Leonards, and P. C. Repetto, "Geotechnical Properties of Municipal Solid Wastes and their use in landfills design," Earth Tech, 1994.
[5] A. T. Musa, "Assessment of the Geotechnical properties of Municipal Solid Waste Incinerator Bottom Ash," Department of Civil Engineering, Bayero University, Kano, Nigeria, 2008.

[6] Methods of Testing for Soils for Civil Engineering Properties (BS 1377), British Standard Institution, London, UK. pp. 143, 1990.

[7] A. A. Bello and C. W. Adegoke, "Evaluation of geotechnical properties of ilesha east southwest nigeria's lateritic soil," Pacific Journal of Science and Technology, vol. 11, no. 2, pp. 617-624, 2010.

[8] R. W. Day, Soil Testing Manual: Procedures, Classification, Data and Sampling Practices, McGraw Hill, Inc. New York, 2001.

[9] O'Flaherty, Highway Engineering, vol. 2, Edward Arnold Publishers, London, UK, 1988.

[10] Federal Ministry of Works and Housing, "General Specifications for Roads and Bridges," Federal Highway Department, Lagos, Nigeria. vol. 2, pp. 145-284, 1997.

A. Y. Abdulfatah holds a $\mathrm{PhD}$ in geo-environmental engineering from Loughborough University (2008) and a Masters Degree in Offshore and Ocean Technology, Specialising in Pipeline Engineering from Cranfield University (2004) both in the UK. He earned his Bachelor Degree in Civil Engineering from Bayero University Kano Nigeria (1992).

He presently lectures in the Department of Civil Engineering, Bayero University, Kano Nigeria.

Dr. Abdulfatah is a member of the following: Nigerian Society of Engineers, British Geotechnical Association, Society for Underwater Technology and Offshore Engineering Society. $\mathrm{He}$ is a reviewer for Journal of Engineering and Technology (ISSN: 1597-5835).

S. G. Kiru holds a bachelors degree in Civil Engineering and a Masters Degree in Geotechnical Engineering from Bayero University, Kano Nigeria. He is a member of the Nigerian Society of Engineers. Engr. Kiru presently heads a Public Works Department in the Ministry for Local Government in Kano State Nigeria.

T. A. Adedokun is an experienced senior academic in the Department of Civil Engineering, Bayero University, Kano Nigeria. He is a member of the Nigerian Mining and Geosciences Society. Mr. Adedokun is presently a $\mathrm{PhD}$ candidate (awaiting external examination) in Water and Environmental Engineering in the same Bayero University Kano. 